\title{
Geological and Hydrochemical Study of the Zalim Spring, Shahrazoor, Sulaimania, Iraq
}

\author{
Salahalddin S. Ali Diary A.M. Ameen \\ Department of Geology \\ College of Science \\ Sulaimania University
}

(Received 29/10/2004 , Accepted 26/1/2005)

\begin{abstract}
Zalim spring which is located about (50 Km) east of Sulaimania city, considered as one of the largest spring in Shahrazoor area. The spring mouth is a semicircular and coming out from a small cave locating about $22 \mathrm{~m}$ above the base of a vertical cliff. This study aims to draw the real geological and hydrogeological setting behind appearance of this wonderful spring. Also an attempt was made to assess the quality of the water, with particular emphasis on the influence of human and tourist's impact on the contamination and pollution of this water during toursting season.

A geological map and a geological cross section were prepared showing the location of the spring, which is based on a detail survey achieved by the authors, covered both Iraq and even Iranian portion of the catchments.

Chemical analysis of water samples were taken from five sites along a route that is more subjecting to human impact than others. The results show satisfactory results according to (WHO) and Iraqi standards for drinking, irrigation and industry uses. Relative increase of Nitrate ions detected and $\mathrm{PO}_{4}$ ions exceeding natural background also detected.

\section{درلسة جيولوجية وهيدوكيميائية لمطاقة عبن زالمشهرنور، السليملنية، العرق}

\section{الملغص}

قع عين زالم على بعد ( · مكم)شرقي مدينة للسليمانية حيث تعتبر من لكبر عيون مطقةشهرزور.

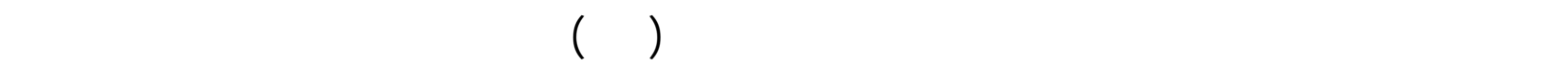

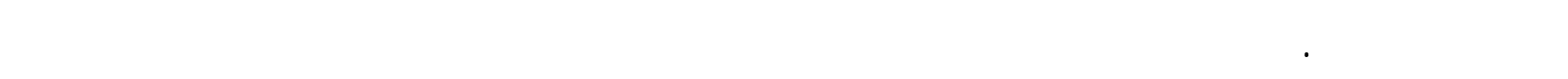

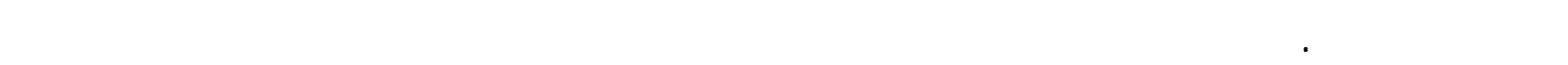
الامطيف. لقد مّ وضع خارطة جيولوجية وبسم مقطع جيولوجي و تحسيد موقع العن، حيث لستند هذا العل على مسح قصصيلي للجانب العراقي والايراني للحوض.

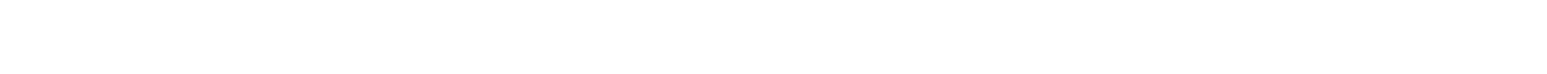
البشري. لظهرت النتائج بان الميل صالحة للثرب عسب المواصفة (WHO) والمواصفة العراقية صالحة
\end{abstract}




\section{للمستخدلم الزراعي والصناعي. هناك زيادة في تركيز ايون النترات علىطول المسارك ذذك تج اوز تركيز ليون الفوسفلت عن الخلفية.}

\section{INTRODUCTION}

The Zalim stream is initiating from the head of Zalim valley as a seasonal stream, but at the middle part, it becomes permanent which is supplied by a spring locally known as Sarchawai Zalim. The spring is important because it has all characteristics to be important as tourism place. The spring supplies, now, Halabja and Khurmal town with drinking water in addition to Zalim and Ahmadawa villages. The high elevation of the spring, with its mean discharge of $\left(2 \mathrm{~m}^{3} / \mathrm{s}\right)$ makes the spring water to be used in the future for drop and spray irrigation. Therefore, the extensive hydrogeological study is urgent issue for this spring. The spring mouth is a semicircular and came out from small cave located about (22) meters above the base of a vertical cliff, which make apart of northeastern side of the valley. From this elevation the water pours out into the valley floor, making a small waterfall (Photo 1B). The valley, being following in the direction of general slope of the area, is called consequent valley, which is deep, steep sided valley, which is known as Zalim valley. It is now yet at youthful stage of development and has $\mathrm{V}$-shape segments, which is formed in the massive limestone of Cretaceous and Jurassic ages by vertical erosion of stream water. In the valley and above the spring many smaller streams are joined the Zalim valley which they all collectively make dendritic drainage pattern. Below the spring, the valley stream became permanent and giving mean discharge of $\left(2 \mathrm{~m}^{3} / \mathrm{s}\right)$ at dry seasons, some times the discharge measured in Ahmed Awa bridge $5 \mathrm{Km}$ down stream reaches $\left(7 \mathrm{~m}^{3} / \mathrm{s}\right)$ at spring season but decease rapidly to less than $\left(0.5 \mathrm{~m}^{3} / \mathrm{s}\right)$ in July and August. This is because of extensive consumption of the water for irrigation of both sides of the Zalim valley, in addition to supplying Ahmadawa and Khurmal towns for domestic purposes.

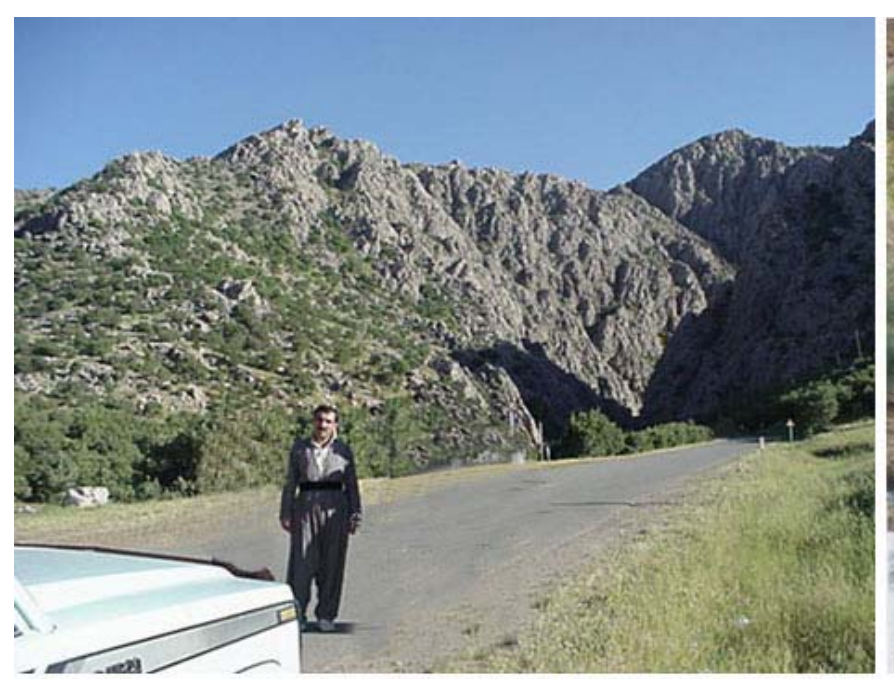

A

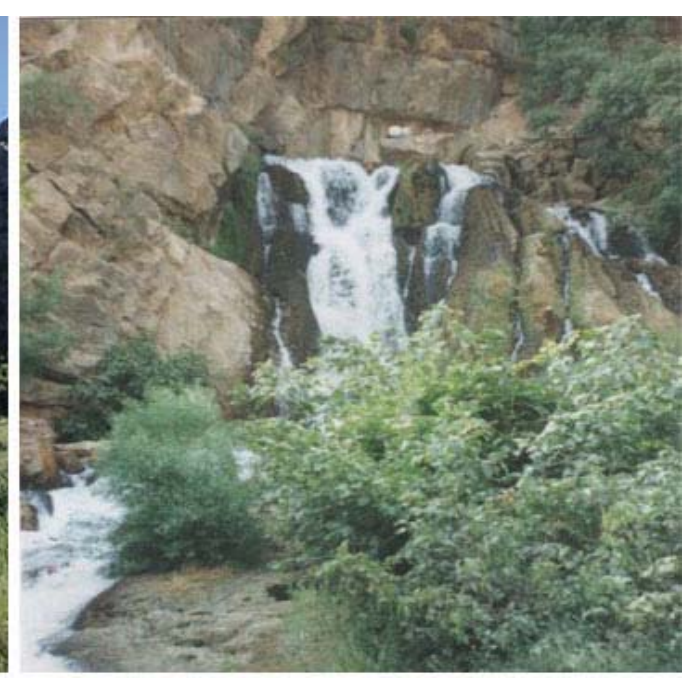

B

Photo 1: A-Outcrop of Avroman Group (Limestone) inside Iran, near Dezily village. B-Zalim spring coming out from Qamchuqa Formation in Zalim valley at southwest side of Avroman mountain. 
What must be mentioned here is that Zalim- Halabja water supply pipeline (which is going to be completed) will lead to decrease $\left(0.5 \mathrm{~m}^{3} / \mathrm{s}\right)$ discharge to about $\left(0.2 \mathrm{~m}^{3} / \mathrm{s}\right)$.

The valley mouth is opened to the plain around Khurmal town. The slope of the valley stream is between (15-20) degrees. In spite of this high degree of the stream gradient, the water has relatively low velocity. This is because the stream flowing on hard rocks and its floor occasionally contains large blocks of limestone, which are fallen from cliffs of both side of the valley. The Zalim valley is formed across the southwestern side of Avroman Mountain (Fig.1). This mountain is observable clearly from everywhere in Shahrazoor plain. It is the highest in the area, which has the elevation of $(2000 \mathrm{~m})$ from the surrounding plains, and its maximum elevation from mean sea level is about (2550 $\mathrm{m})$. The steep slope of the mountain bends at its base concavely downward to form the foot of the mountain, which, merges in to the broad Shahrazoor plain through a narrow hilly strip.

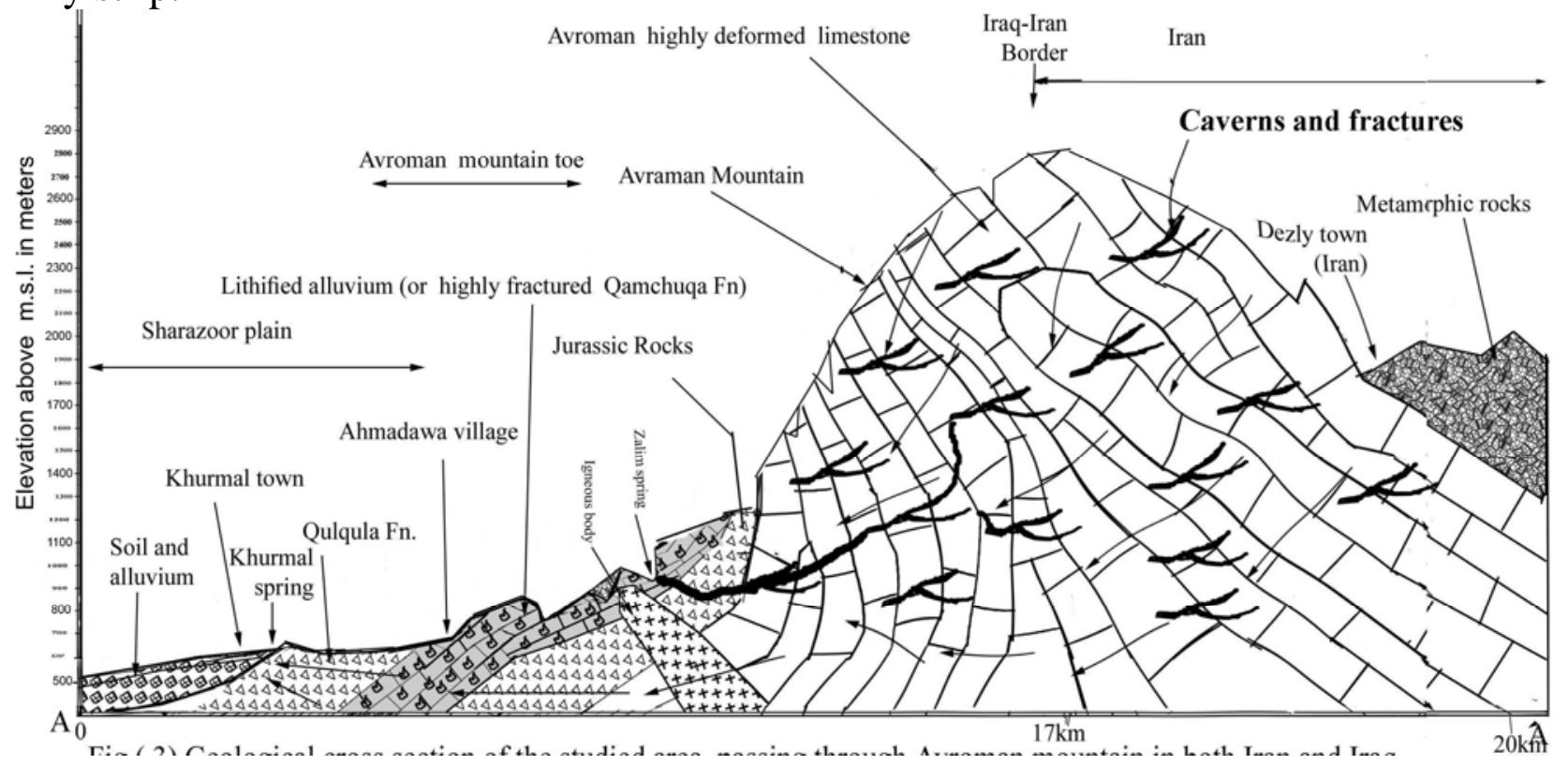

Fig.1: Geological cross section of the studied area passing through Avroman mountain in both Iran and Iraq.

\section{GEOGRAPHIC LOCATION}

The studied area is located, about $(50 \mathrm{~km})$ to the east of Sulaimania city, NE of Iraq and about $(10 \mathrm{~km})$ to the north of Hallabja Town. According to latitude and longitude the center of the area is located at the intersection of $\left(35^{0} 17^{-}\right)$and $\left(46^{0} 04^{-}\right)$degrees, respectively (Fig.2). The area include of Ahmad Awa village inside a gorge, where Zalim stream bend to the south, at that site a weir is built on the river to divert two canals for irrigation of the area located to the north and northeast of Khurmal town.

\section{GEOLOGY OF THE WATER BERARING FORMATIONS (AQUIFERS)}

In this study the stratigraphic units (Formation and Groups) are described according to hyrogeological properties (as permeability and type of the characteristic porosities) of each ones. This depends on the descriptions and classification of lithology on each unit, which is started from the older formations and groups to the younger ones in the watershed of the Zalim stream. 


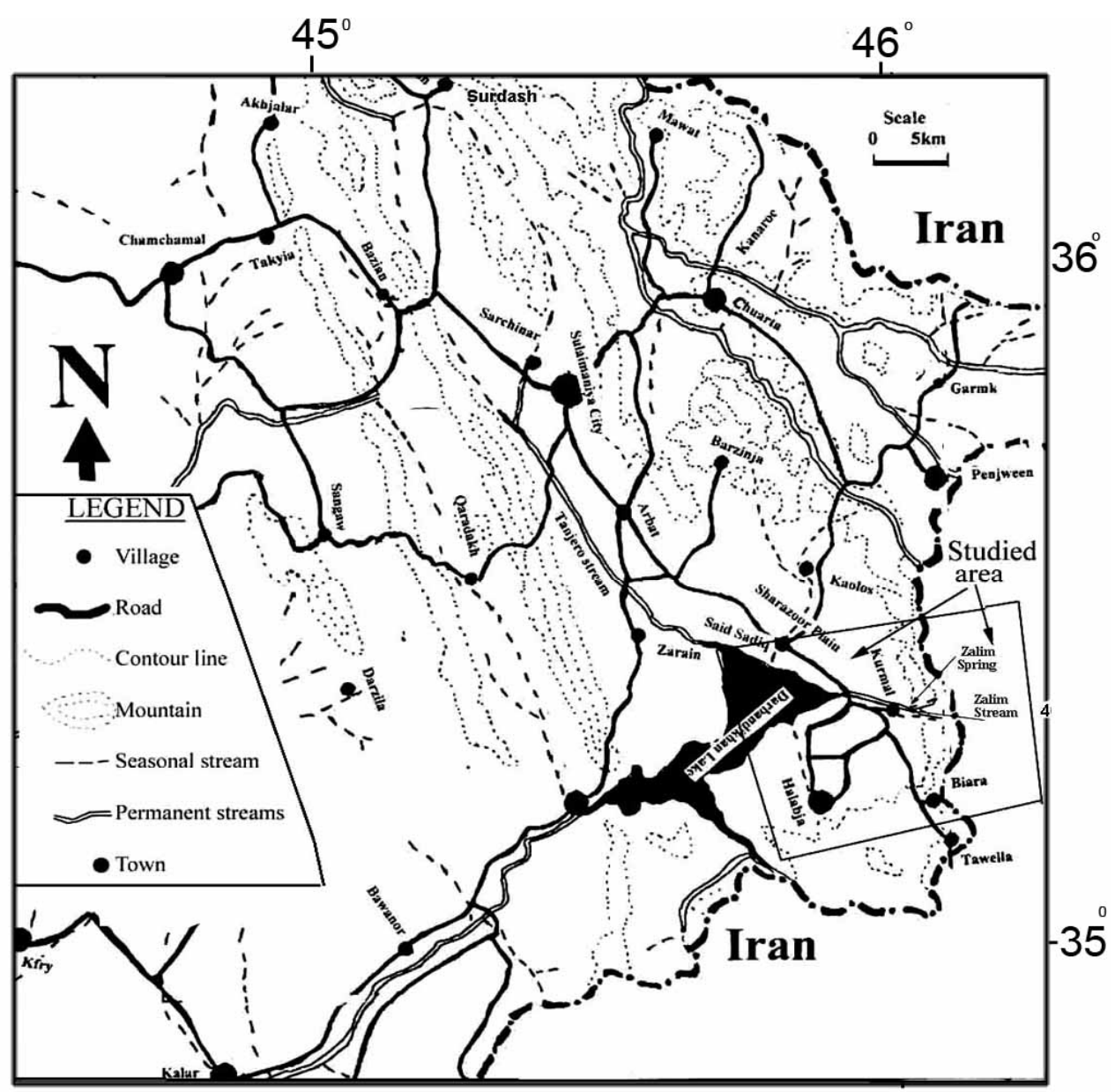

Fig.2: Location map of the studied area.

When the tectonic classification of (Buday and Jassim, 1987) is used, this watershed located within the High Folded Zone or Imbricated Zone of (Buday, 1980) of Iraqi territory. The entire surface and possibly all the ground water of this basin are draining to the Darbandikhan Lake through Zalim stream (Fig.2). This basin is characterized by extensive annual recharge area where high rate of rain and snow precipitation occur in spring and winter seasons. Some of the rainfall is discharged as surface runoff while due to the intense fracturing of the rocks, most of the rainfall is infiltrating into ground and discharges as spring water, such as Zalim and Khurmal springs and a relatively good quantity of infiltrated water remain in ground which can be used by drilling suitable wells. This makes fewer precautions to be required in exploitation of ground water in this basin, as has extensive recharge area.

\section{Avroman Group:}

This group is the oldest (Triassic) unit in the Zalim basin, which is exposed above the contour line of $(950 \mathrm{~m})$ and extends inside Iran territory so that most parts located in this country (Photo 1A). It consists of thick brecciaed grey limestone and dolomitic limestone. It has a thickness of more than $(1000 \mathrm{~m})$ and till now it is not differentiated into smaller units, (i.e. formations). The measurement of the dip and strike of the layers is very difficult. Nevertheless, their dip near the mountain bases (toes) is about (40) degree while along the slope reach more than (60), and in some places it is possible to found the layers of this group overturned (more than 90degrees). 
During fieldwork inside Iran it is proved that nearly all stored water inside this group is discharged through Zalim spring. This discharge includes that part located inside Iraq and most parts inside Iran too. It is proved that this spring is not related to the wellknown Zirebar Lake (Marivan Lake) (Mariwan District, NW Iran), this is because the lake is supplied partly by surface runoff and groundwater of the Avroman Group and partly by Qandil metamorphic Group

The main porosities of this group are joints, fractures and cavities. These porosities are more or less locally developed into caverns or large caves especially at the intersection of ancient or recent water table with topography.

The Avroman Group has very helpful effects on ground water in eastern part of the Shahrazoor plain. This is because:

1. It has very high thickness which can store large quantity of ground water in its effective porosities which now supplying several large springs at its foothill, among these springs, Zalim, Reshen (west of Zalim) and Khurmal springs. Even the ground water of the Iranian part is discharged by this spring.

2. This type of rock located in the high elevation, more than (1500) meters from the surrounding Shahrazoor plains. So it caused elevation of water table in the area. This is demonstrated clearly in Shahrazoor plain, which in some localities has zero depth of ground water table and make some swamps.

\section{Qulqula Formation:}

This Formation is exposed in the valleys (e.g. Zalim valley) which dissecting the Avroman Mountain across the southwestern side which is looking over Shahrazoor plain. It is also exposed around Khurmal town (Figs. 1 and 3). The dissecting is contributed mainly to vertical and lateral erosion of seasonal streams during thousands of years. This formation is composed of alternation of bedded chert, limestone and marl.

Because of the high content of shale, this Formation is impervious and acting as barrier for ground water to seep as springs, such as Zalim spring. In addition to that there is another reason for this spring to be in present position that is what has seen by us which demonstrated by an igneous body below the spring. It is hard and impervious. This fact also seen by us (Fig.1).

\section{Qamchuqa Formation:}

Although the Zalim spring is pouring out from this formation, it forms not an aquifer for the water. Because the thickness is low and most of it removed by weathering. As we mentioned that the ware comes from the Avroman Group. It consists of gray, massive dolomitic limestone with thickness more than 300 meters but decreased as dissected by the valleys (Photo.1A). In some place the formation is so deformed and brecciaed that it cannot be distinguished from lithified old alluvial deposits.

\section{Recent alluvial sediments:}

Nearly all the surface of the eastern parts of Shahrazoor plain including lower part of Zalim basin is covered with thick (layer) of fluvial and alluvial deposits. They are consisting of unconsolidated mixture of detritus clay, silt, sand and gravel. They are overlying Qulqula, Kometan Formations in the areas near to Sureen and Avroman Mountain (Fig. 1). But in the more inner areas, i.e., such as areas around Darbandikhan Lake, they are covering Shiranish and Tanjero Formations. At the lower slope of the Avroman Mountain the alluvium are clearly mixed with different angular sizes of broken 
fragment of limestone of and chert, forming what are known as talluviums, which are formed by gravity.driven broken clasts of rocks exposed along southwestern side of the mountain The alluvium thickness can be known from the drilled wells in the area, which is reported to varying from (zero to 200) meters. This thickness is including two horizons:

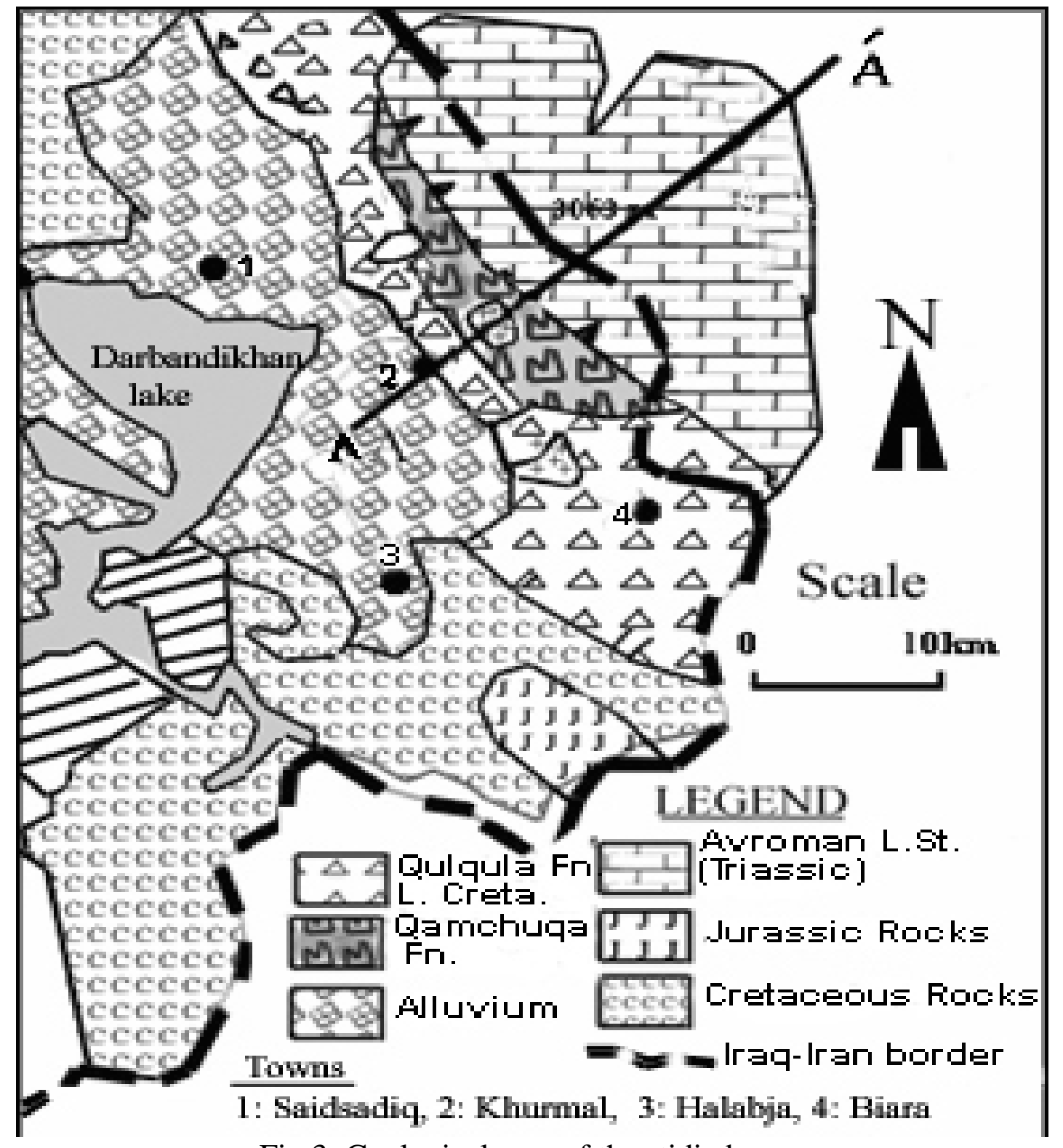

Fig.3: Geological map of the stidied area.

a) Flood plain (upper horizon) composed mainly of silt, clay and less gravelly deposits. This part has low permeability and its thickness decrease toward Avraman Mountain, which became zero below Ahmadawa village. But it may reach (60) meters around Grdi Go(near Said Sadiq town).

b) Bed load (lower horizon), which composed of sand and gravel. Some times this part replaced by talluvium and colluvium near the mountains toes. 
Many hand dug gently inclined underground channels are excavated for increasing ground water. They are locally called Karhez. These are used for conducting and collecting groundwater by gravity from alluviual, or talluvial deposits to outside of the earth. These karezes were very valuable for villages during wet episodes but most of them were dried out during the last dry two years.

\section{Materials and Methods:}

\section{HYDROCHEMISTRY}

During the 28/9/2003, five water samples were collected at different locations along the outlet of the spring (Fig.4). All water samples were stored in (500 ml) polythelene bottles and stored in a cool box until analysis in the (Health and Environmental Protection Office Lab.). In the field $\mathrm{pH}$, Ec, Tc were measured using (Digital $\mathrm{pH}, \mathrm{Ec}$, Tc meter type, Hatch 2000), Ca and Mg were measured volumetrically by (EDTA) using (E.B.T.) indicator. $\mathrm{Na}$ and $\mathrm{K}$ were determined with digital flame photometer type (Genway PFP7). Bicarbonate was measured by acid titration using Methyl orange indicator. $\mathrm{CO}_{3}$ by EDTA using Phenolnephtalene indicator. Chloride by $\mathrm{AgNO}_{3}$. TDS by evaporation. $\mathrm{NO}_{3}{ }^{-}, \mathrm{NO}_{2}{ }^{-}, \mathrm{PO}_{4}{ }^{3-}, \mathrm{NH}_{3}, \mathrm{NH}_{4}{ }^{+}, \mathrm{SO}_{4}{ }^{2-}$ determined spectophotometrically using type (Hatch DR 2010) spectrophotometer(APHA, 1995).

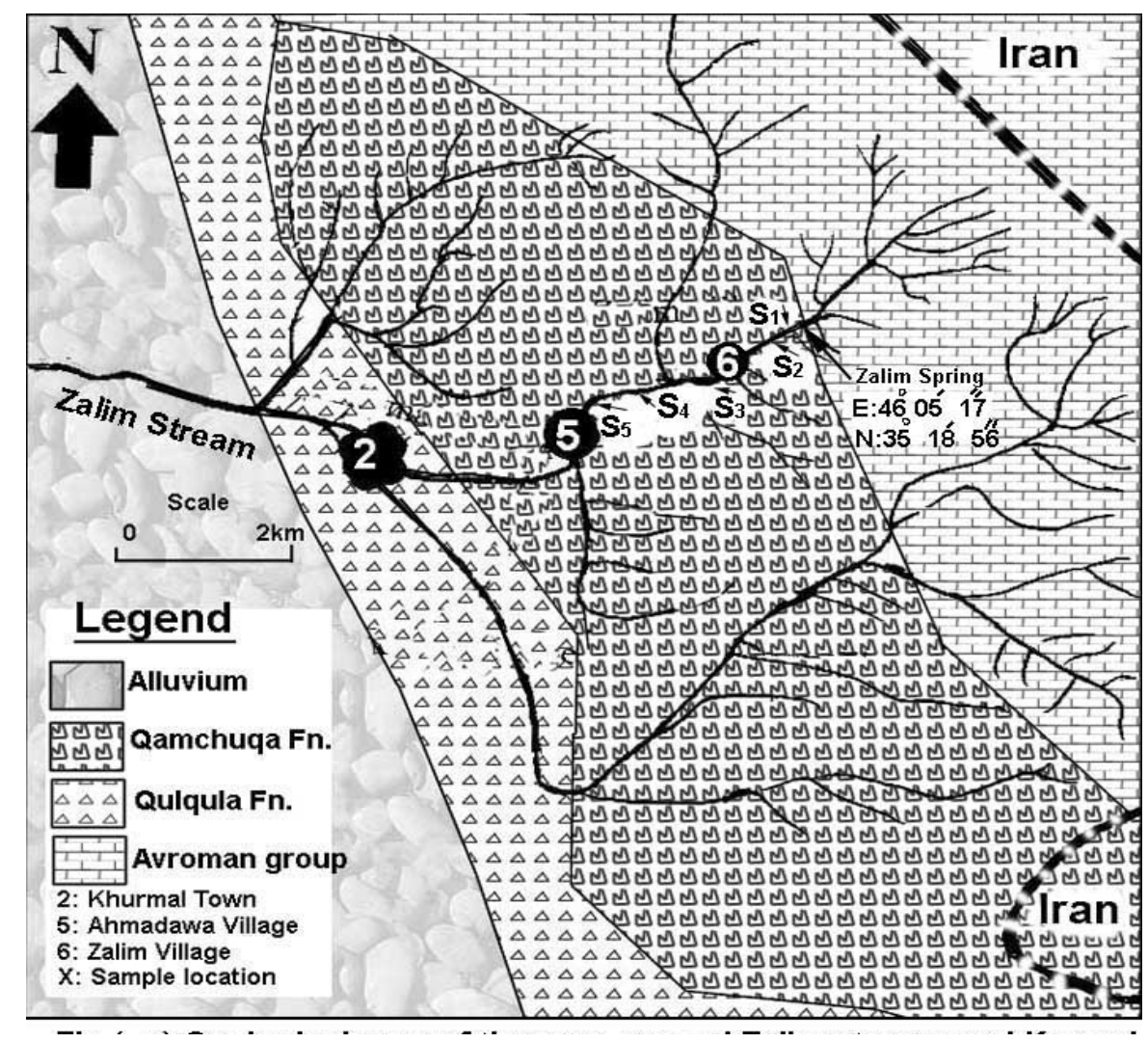

Fig.4: Geological map of the area around Zalim stream and Khurmal town.

\section{Chemical characteristics of water samples:}

\section{1-Major ions concentration:}

The results of chemical analysis of water samples tabulated in the table (1). In the sample No.(1,5), Calcium and Bicarbonate are the dominant ions, in the sample No.(2,3,4). Magnesium and Bicarbonate are the dominant ions. The second species in 
abundance are Sodium for cations and Chloride in sample No.(1,2) and Sulfate in sample No.(3,4,5) for anions. Calcium range from (27-32) mg/l, Magnesium range from (2830.4) mg/l, Potassium from (0.27-0.35) mg/l, Sodium from (0.99-1.4) mg/l, Chloride from (6.7-9.9) mg/l, Sulfate from (0.96-15) mg/l, Bicarbonate from (183-232) mg/l. The predominant of calcium and magnesium ions is attributed to the weathering processes of limestone and dolomite rocks. Also the predominant of bicarbonate attributed of same processes above (Drever, 1997).

Table 1: Major ions concentrations for water samples.

\begin{tabular}{|c|c|c|c|c|c|c|c|c|c|c|c|c|c|c|c|}
\hline No. & Tc & PH & $\begin{array}{c}\text { Ec } \\
\mathrm{uc} / \mathrm{cm}\end{array}$ & $\begin{array}{l}\text { TDS } \\
\text { mg/l }\end{array}$ & unit & $\mathrm{Ca}^{2+}$ & $\mathbf{M g}^{2+}$ & $\mathrm{Na}^{+}$ & $\mathbf{K}^{+}$ & SUM & $\mathrm{SO}^{2-}$ & $\mathrm{Cl}^{-}$ & $\mathrm{HCO}_{3}{ }^{-}$ & $\mathrm{CO}_{3}{ }^{2-}$ & SUM \\
\hline \multirow{3}{*}{ S1 } & \multirow{3}{*}{13} & \multirow{3}{*}{7.53} & \multirow{3}{*}{460} & \multirow{3}{*}{325} & ppm & 32 & 30 & 1.15 & 0.27 & 63.42 & 1.9 & 9.9 & 232 & n.d & 307.2 \\
\hline & & & & & epm & 1.62 & 2.47 & 0.05 & 0.007 & 4.15 & 0.04 & 0.28 & 3.8 & n.d & 4.12 \\
\hline & & & & & \%ерm & 39 & 59.5 & 12 & 0.17 & 100 & 0.97 & 6.8 & 92.2 & n.d & 100 \\
\hline \multirow{3}{*}{ S2 } & \multirow{3}{*}{14} & \multirow{3}{*}{7.32} & \multirow{3}{*}{435} & \multirow{3}{*}{313} & ppm & 30 & 30.4 & 1.15 & 0.27 & 61.82 & 0.96 & 8.17 & 220 & n.d & 291 \\
\hline & & & & & epm & 1.5 & 2.5 & 0.05 & 0.007 & 4.06 & 0.02 & 0.23 & 3.6 & n.d & 3.85 \\
\hline & & & & & \%ерm & 37 & 61.6 & 1.2 & 0.17 & 100 & 0.52 & 5.8 & 93.5 & n.d & 100 \\
\hline \multirow{3}{*}{ S3 } & \multirow{3}{*}{14.5} & \multirow{3}{*}{7.25} & \multirow{3}{*}{370} & \multirow{3}{*}{263} & ppm & 28 & 30.4 & 0.99 & 0.27 & 59.66 & 10 & 6.7 & 183 & n.d & 259.4 \\
\hline & & & & & epm & 1.4 & 2.5 & 0.043 & 0.007 & 3.95 & 0.21 & 0.19 & 3 & n.d & 3.4 \\
\hline & & & & & \%ерm & 35.4 & 63.3 & 1.1 & 0.18 & 100 & 6.18 & 5.6 & 88.2 & n.d & 100 \\
\hline \multirow{3}{*}{ S4 } & \multirow{3}{*}{14.6} & \multirow{3}{*}{7.3} & \multirow{3}{*}{378} & \multirow{3}{*}{270} & ppm & 27 & 28 & 1.15 & 0.27 & 56.42 & 13 & 7.1 & 183 & n.d & 259.5 \\
\hline & & & & & epm & 1.35 & 2.32 & 0.05 & 0.007 & 3.73 & 0.27 & 0.2 & 3 & n.d & 3.47 \\
\hline & & & & & \%ерm & 36.2 & 62.2 & 1.34 & 0.19 & 100 & 7.8 & 5.76 & 86.5 & n.d & 100 \\
\hline \multirow{3}{*}{ S5 } & \multirow{3}{*}{15} & \multirow{3}{*}{7.31} & \multirow{3}{*}{400} & \multirow{3}{*}{293} & ppm & 30 & 28 & 1.4 & 0.35 & 59.75 & 15 & 8.9 & 183 & n.d & 266.7 \\
\hline & & & & & epm & 1.5 & 2.3 & 0.06 & 0.007 & 3.87 & 0.31 & 0.25 & 3 & n.d & 3.56 \\
\hline & & & & & \%ерm & 38.76 & 59.4 & 1.6 & 0.23 & 100 & 8.7 & 7 & 84.3 & n.d & 100 \\
\hline Max. & 15 & 7.53 & 460 & 325 & & 32 & 30.4 & 1.4 & 0.35 & & 15 & 9.9 & 232 & & \\
\hline Min. & 13 & 7.25 & 370 & 263 & & 27 & 28 & 0.99 & 0.27 & & 0.96 & 6.7 & 183 & & \\
\hline Aver. & 14.22 & 7.34 & 408.6 & 292.8 & & 29.4 & 23.28 & 1.17 & 0.22 & & 8.17 & 8.15 & 200.2 & & \\
\hline
\end{tabular}

\section{2-Minor Ion concentration:}

The concentration of $\mathrm{NO}_{3}^{-}, \mathrm{NO}_{2}^{-}, \mathrm{PO}_{4}^{3-}, \mathrm{NH}_{3}, \mathrm{NH}_{4}^{+}$are given in table (2). The concentration of these ions are generally low comparing with (WHO, 1998) standard except $\mathrm{PO}_{4}{ }^{3-}$.

Table 2: Major ions concentrations, TH and SAR for water samples.

\begin{tabular}{|c|c|c|c|c|c|c|c|}
\hline No. & $\begin{array}{l}\mathrm{NO}_{3} \\
\mathrm{mg} / 1\end{array}$ & $\begin{array}{l}\mathrm{NO}_{2} \\
\mathrm{mg} \boldsymbol{I}\end{array}$ & $\begin{array}{l}\mathbf{P O}_{4} \\
\mathrm{mg} \operatorname{n}\end{array}$ & $\begin{array}{l}\mathrm{NH}_{\mathbf{3}} \\
\mathrm{mg} \boldsymbol{M}\end{array}$ & $\begin{array}{l}\mathrm{mH}_{4} \\
\mathrm{mg} \boldsymbol{A}\end{array}$ & $\begin{array}{c}\text { TH } \\
\mathrm{mg} n\end{array}$ & SAR \\
\hline S1 & 12.4 & 0.88 & 0.87 & 0.13 & 0.14 & 203 & 0.035 \\
\hline 52 & 13.5 & 0.88 & 0.95 & 0.15 & 0.16 & 200 & 0.035 \\
\hline 53 & 14 & 0.92 & 0.92 & 0.16 & 0.17 & 195 & 0.031 \\
\hline 54 & 18.5 & 0.95 & 1.05 & 0.18 & 0.19 & 183 & 0.037 \\
\hline 55 & 20 & 0.98 & 1.1 & 0.2 & 0.22 & 190 & 0.044 \\
\hline Max. & 20 & 0.98 & 1.1 & 0.2 & 0.22 & 203 & 0.044 \\
\hline Min. & 12.4 & 0.88 & 0.87 & 0.13 & 0.14 & 183 & 0.031 \\
\hline Awe & 15.7 & 0.92 & 0.98 & 0.16 & 0.18 & 194 & 0.036 \\
\hline
\end{tabular}




\section{Water hardness:}

This is the property that causes precipitation Of ordinary soup. it results from presence of calcium and magnesium in combination with carbonate and bicarbonate ions (Shieded et al., 1998). The hardness of water samples range from (183 mg/l) to (203 $\mathrm{mg} / \mathrm{l}$ ) (Table 2) .According to French degree which is one degree equal to (10 $\mathrm{mg} / \mathrm{l}$ $\mathrm{CaCO}_{3}$ ) (Detay, 1997). The water of studied area is moderately hard and the type of it is temporary hardness.

\section{Water Quality type according to Pipers' classification:}

Figure (5) shows the major solute concentration plotted on a Piper trilinier diagram (Piper, 1944). One geochemical grouping was defined which is located in the field No.(5) that means secondary alkalinity (Carbonate hardness) exceeds 50\% with TDS values between (263-325) $\mathrm{mg} / \mathrm{l}$, and the type of water is $\left(\mathrm{Mg}-\mathrm{HCO}_{3}\right)$. The $\left(\mathrm{Mg}-\mathrm{HCO}_{3}\right)$ type waters are consistent with what is expected from the water rock interactions in dolomite and limestone beds.

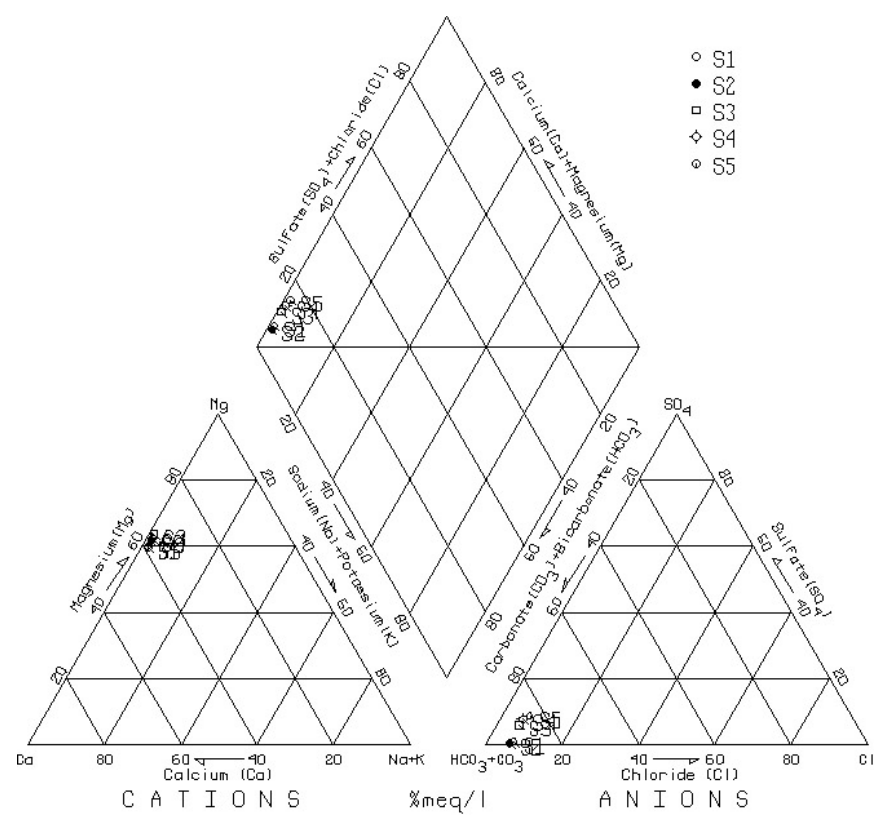

Fig. 5: Piper Diagram for water samples

\section{Evaluation of water for different purposes:}

The hydrochemical study aims to evaluate Zalim spring for domestic, livestock, agricultural, and industrial purposes.

\section{1-Drinking and domestic evaluation:}

Water for drinking and domestic uses should be clear and free from excessive dissolved solids as well as harmful organism (WHO, 1998). In general, Zalim spring can be considered chemically as suitable for drinking according to (WHO, 1998) and Iraqi (1998) standard (Table 3).

\section{2-Livestock purpose evaluation of water samples:}

For such purpose (Ayers and Westcot, 1989) standard used to evaluate water samples (Table 4). The application of such standard show that all water samples are suitable for livestock and poultry requirements. 
Table ( 3 ) standard for drinking water

\begin{tabular}{|c|c|c|}
\hline Constituents & $\begin{array}{c}\text { Iraqi } \\
\text { Standard } \\
\mathbf{1 9 9 8}\end{array}$ & $\begin{array}{c}\text { WHO } \\
\text { Standard } \\
\mathbf{1 9 9 6}\end{array}$ \\
\hline $\mathbf{C a}$ & 50 & 75 \\
\hline $\mathbf{M g}$ & 50 & 125 \\
\hline $\mathbf{N a}$ & 200 & 200 \\
\hline $\mathbf{K}$ & - & 12 \\
\hline $\mathbf{C l}$ & 250 & 250 \\
\hline $\mathbf{S O}_{4}$ & 250 & 250 \\
\hline $\mathbf{N O}_{3}$ & 40 & 50 \\
\hline $\mathbf{N O}_{2}$ & 3 & 3 \\
\hline $\mathbf{P O}_{4}$ & - & 0.4 \\
\hline $\mathbf{T H}$ & 500 & - \\
\hline $\mathbf{T D S}$ & 1000 & 1000 \\
\hline $\mathbf{p H}$ & $7-8.5$ & $6.5-8.5$ \\
\hline
\end{tabular}

Table(4) Water quality Guide For

\begin{tabular}{|c|c|}
\hline $\begin{array}{c}\mathbf{E c}(\boldsymbol{\mu} \\
\mathbf{m o h s} / \mathbf{c m})\end{array}$ & Rating \\
\hline$<1500$ & Excellent \\
\hline $1500-5000$ & Very Satisfactory \\
\hline $5000-8000$ & $\begin{array}{c}\text { Satisfactory for livestock, } \\
\text { benefit for poultry }\end{array}$ \\
\hline $8000-11000$ & $\begin{array}{c}\text { Limited use for livestock, } \\
\text { unfit for poultry }\end{array}$ \\
\hline $11000-16000$ & Very limited use \\
\hline$>16000$ & Not recommended \\
\hline
\end{tabular}

\section{3-Irrigation purpose evaluation of water samples:}

Wilcox diagram (at the U.S. Salinity Laboratory, 1954) is used for evaluation of water samples (Fig. 6). Accordingly the spring water samples characterized by low Sodium hazard (S1) and medium Salinity hazard (C2), as they classified as (C2S1).

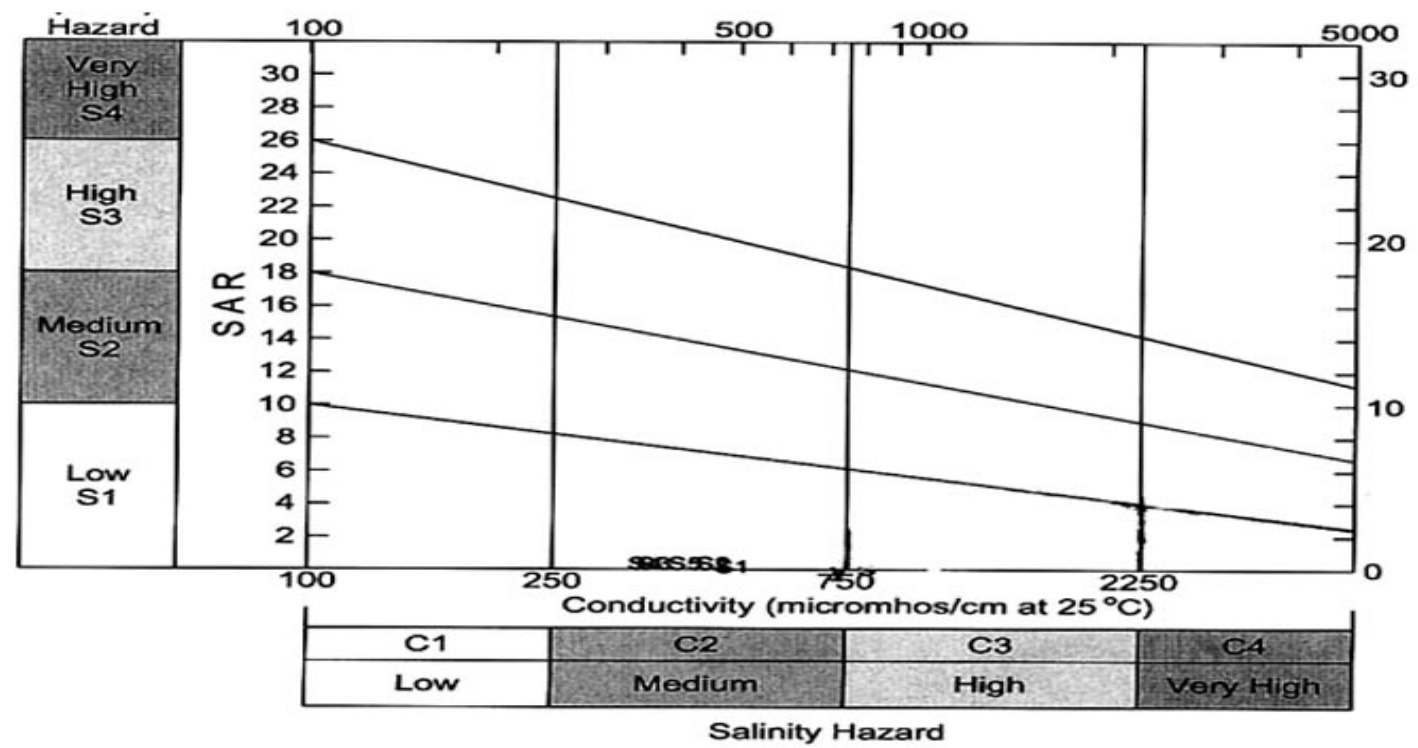

Fig.6: Wilcox diagram for classification of water samples for irrigation purposes.

\section{4-Industrial purpose evaluation of water samples:}

According to (Hem, 1989) standard Zalim spring can be accepted safely for all industrials except for wood chemical and canned, dried and frozen fruits and vegetables (Table 5). 
Table 5: Water quality requirements for selected industries and processes by (Hem, 1989).

\begin{tabular}{|c|c|c|c|c|c|c|c|c|c|c|}
\hline \multirow{2}{*}{ ن̈ } & \multirow[b]{2}{*}{ Textile } & \multicolumn{2}{|c|}{$\begin{array}{c}\text { Chemical pulp } \\
\text { and paper }\end{array}$} & \multirow{2}{*}{$\begin{array}{c}\text { Wood } \\
\text { chemicals }\end{array}$} & \multirow{2}{*}{$\begin{array}{l}\text { Synthetic } \\
\text { rubber }\end{array}$} & \multirow{2}{*}{$\begin{array}{c}\text { Petroleum } \\
\text { product }\end{array}$} & \multirow{2}{*}{$\begin{array}{l}\text { Canned ,dried } \\
\text { and frozen } \\
\text { fruits and } \\
\text { vegetable }\end{array}$} & \multirow{2}{*}{$\begin{array}{c}\text { Soft } \\
\text { drinks } \\
\text { bottling }\end{array}$} & \multirow[b]{2}{*}{$\begin{array}{l}\text { Leather } \\
\text { tanning }\end{array}$} & \multirow{2}{*}{$\begin{array}{c}\text { Hydraulic } \\
\text { cement } \\
\text { manufacture }\end{array}$} \\
\hline & & Unbleached & Bleached & & & & & & & \\
\hline $\mathrm{Ca}^{2+}$ & 0 & 20 & 20 & 100 & 80 & 75 & -- & 100 & -- & -- \\
\hline $\mathrm{Mg}^{2+}$ & 0 & 12 & 12 & 50 & 36 & 30 & -- & -- & -- & -- \\
\hline $\mathrm{Cl}^{-}$ & 0 & 200 & 200 & 500 & -- & 300 & 250 & 500 & 250 & 250 \\
\hline $\mathrm{HCO}_{3}^{-}$ & 0 & -- & -- & 250 & -- & -- & -- & -- & -- & -- \\
\hline $\mathrm{SO}_{4}{ }^{2-}$ & 0 & -- & -- & 100 & -- & -- & 250 & 500 & 250 & 250 \\
\hline $\mathrm{NO}_{3}{ }^{-}$ & 0 & -- & -- & 5 & -- & -- & 10 & -- & -- & -- \\
\hline TH & 25 & 100 & 100 & 900 & $350 *$ & 350 & 250 & -- & Soft & -- \\
\hline TDS & 100 & -- & -- & 1000 & -- & 1000 & 500 & -- & -- & 600 \\
\hline $\mathbf{p H}$ & $\begin{array}{l}2.5- \\
10.5\end{array}$ & $6-10$ & $6-10$ & $6.5-8$ & $6.2-8.3$ & $6-9$ & $6.5-8.5$ & -- & $6-8$ & $6.5-8.5$ \\
\hline $\mathbf{T}\left({ }^{\circ} \mathbf{F}\right)$ & -- & -- & 95 & -- & -- & -- & -- & -- & -- & -- \\
\hline
\end{tabular}

\section{Dissolution of minerals in the aquifer:}

In order to understand the rate of dissolution of minerals inside the aquifer and the geochemical situation, sample No.1 used and interred to (Aquachem, 2003) program because this sample is directly taken from the outlet of the spring and not affected by the anthropogenic activity. The output of the program indicates that dolomite is the essential mineral in the aquifer and each $(1.234 \mathrm{mmol} / \mathrm{l})$ dissolved to give that chemistry of water (Table 6).

Table (6) dissolved minerals in the aquifer.

\begin{tabular}{|c|c|c|}
\hline Dissolved Minerals & $\mathbf{m g} / \mathbf{l}$ & $\mathbf{~ m m o l} / \mathbf{l}$ \\
\hline $\begin{array}{c}\text { Dolomite } \\
\left(\mathbf{C a M g}\left(\mathbf{C O}_{3}\right)_{2}\right)\end{array}$ & 2.926 & 1.234 \\
\hline $\begin{array}{c}\text { Anhydrite } \\
\left(\mathbf{C a S O}_{4}\right)\end{array}$ & 2.694 & 0.05 \\
\hline $\begin{array}{c}\text { Halite } \\
(\mathbf{N a C l})\end{array}$ & 227.19 & 0.02 \\
\hline
\end{tabular}

\section{Contamination of the spring:}

Zalim is the most wonderful tourist area, the tourists come to it in the summer but they affect the spring by putting the waste in to it. Due to this anthropogenic activity, Nitrate ions increased along the path of water, under aerobic condition bacteria can oxidize $\mathrm{NH}_{3}$ to $\mathrm{NO}_{2}$ and $\mathrm{NO}_{2}$ to $\mathrm{NO}_{3}$ (Pierce et al., 1998) The source of it is from detergents and untreated sewage (Panno et al., 2001) which put into the water by the rural pupil and the tourists in the area also come from fertilizer, all water samples are polluted with $\left(\mathrm{PO}_{4}{ }^{3-}\right)$ because it exceeds the background which is $(0.1 \mathrm{mg} / \mathrm{l})$ (Mckenzie, 2001) and increased with flow path. The source of this ion is from waste and detergents and fertilizer (Alloway and Ayres, 1997). $\mathrm{SO}_{4}$ increased along the path also, the reason of this increasing is same of Nitrate and the source is from detergents (Drever, 1997). This increasing of such ions is contaminating the water but not pollute the water except $\left(\mathrm{PO}_{4}^{3}\right)$. 


\section{CONCLUSIONS}

The paper has the following conclusions:

-The main aquifer of the spring water is mainly returned to Avroman Limestone Group that located across Iranian and Iraqi borders.

-The high elevation of the spring is attributed to impervious units (formations) such as Qulqula Formation is regarded which stand as a barrier for ground water leaking to lower elevation.

-The fieldwork inside Iranian territory showed that the spring has no any relation to Zirebar Miwan Lake.

-The hydrochemical study showed that the water type is $\mathrm{Mg}-\mathrm{HCO}_{3}$ type and the spring is contaminated with $\mathrm{NO}_{3}$ and polluted with $\mathrm{PO}_{4}$ due to anthropogenic activity, when the water evaluated for different purposes it is concluded that the water is suitable for drinking, agricultural, livestock, poultry and industrial purposes.

-The main mineral dissolved in the aquifer is dolomite.

\section{REFERENCES}

APHA, AWWA and WPCF, 1995. Standard methods for the examination of water and waste water. American Public Health Association, $19^{\text {th }}$ ed., Washington.

Alloway, B. and Ayres, D.C., 1997. Chemical principles of environmental pollution ( $2^{\text {nd }}$ ed.). Chapman and Hall, London, 395p.

Ayers, R.S. and Westcot, D.W., 1989. Water quality for agriculture, irrigation and drainage, Paper 29, Rev. 1, FAO, Rome, Italy, 174p.

Buday, T., 1980. Regional Geology of Iraq: Vol. 1 Stratigraphy, D.G. Geol. Surv. Min. Invest. Publ., 445p.

Buday, T. and Jassim, S.Z., 1987. The regional geology of Iraq, Vol.II Tectonism, magmatism and metamorphism, 352p.

Detay, M., 1997. Water wells-implementation, maintenance and restoration. John Wiley and Sons, London, 379p.

Drever, J.I.., 1997. The geochemistry of natural water, surface and groundwater environments ( $3^{\text {rd }}$ ed.). Prentice Hall, USA, 436p.

Hem, J.D., 1985. Study and interpretation of the chemical characteristics of natural water. USGS Water Supp. Paper 2254, 263p.

IGS, 1998. Iraqi guideline standard for drinking water (in Arabic).

McKenzie, J.M., Sigel, D.I., Patterson, W. and McKenzie, D.J., 2001. A geochemical survey of spring water from the main Ethiopian rift valley, southern Ethiopia: implications for well-head protection. Hydrogeology J., Vol.9, pp.256-272.

Panno, S.V., Hackley, K.C., Hawang, H.H., Kelly, W.R., 2001. Determination of the sources of nitrate contamination in karst springs using isotopes and chemical indicators. Chemical geology, Vol.179, pp.113-128.

Pierce, J.J., Weiner, R.F. and Vesilind, P.A., 1998. Environmental pollution and control ( $4^{\text {th }}$ ed.). Butterworth-Heinemann, USA, 392p.

Piper, A.M., 1944. A graphic procedure in geochemical interpretation of water analysis. Trans. Am. Geophys. Union, Vol.25, pp.914-923.

Shided, A.G, Yehia, M.M., 1998. Hydrogeochemical studies for the groundwater in AinFurtuga area, south Sinai, Egypt: Egyptian Journal of Geology, Vol.42/2, pp.713735. 
U.S. Salinity Laboratory Staff, Richards L.A., 1954. Diagnosis and improvement of saline and alkali soils. Dept. Agric. Handbook, Vol.60, Washington, D.C., p.1-82.

Waterloo Hydrogeologic Inc., 2003. Software package (Aquachem) for Graphical and Numerical analysis and modeling of water quality data.

WHO, 1998. Guidelines for drinking water quality, $3^{\text {rd }}$ ed., Vol.II., Geneva, 951p. 